\title{
A clash of paradigms: populism and theory building'
}

\author{
Irene Kögl \\ Diplom Kulturwirtin (Universität Passau) \\ Pesquisadora do Instituto de Estudos Europeus (Universität Passau) \\ Passau, Alemanha \\ irene.koegl@uni-passau.de
}

\begin{abstract}
Research on populism often appears to be opaque due to the fact that populism is a label attributed to a variety of phenomena. However, failures to build a theory of populism are not just mere consequences of a blurred object of study - they also result from ontological and epistemological clashes between the dominating research paradigms precisely because debates do not consider the limits inherent to analytical strategies. This paper shows which paradigms structure the field of populism research and evaluates the resulting approaches considering their outcomes and impasses. Furthermore, it enunciates suggestions on the issue of how some additional value can be obtained from this. As a result, this paper's contribution is an attempt to systematize a highly fragmented debate whereas it does not point at content-related discussions but rather at the pragmatic handling of research paradigms.
\end{abstract}

Key words: populism, theory building, ontology, epistemology, research paradigms.

\section{Populism - What's beneath the label?}

$\mathrm{T}$ HE ASSERTION THAT THERE IS NO "theory of populism" is not just a frequent quip - on closer examination it even appears to be the least common denominator for a highly fragmented research field that circles around one fundamental problem: to find a definition for a label that surrounds political movements (Minogue, 1969; Di Tella, 1997, p. 196; Vilas, 1994, p. 37f $)^{2}$ as well as "post-industrial parties" (Frölich-Steffen et al., 2005, p. 4; Mudde, 2004, p. 541; Touraine, 2007, p. 38), dimensions of political culture (Worsley, 1969), modes of political articulation (Kazin, 1998) ${ }^{3}$ and certain political styles (Decker, 2006; Knight, 1998; Viguera, 1993). Consequently, the existing studies encompass broad thematic distances and, therefore, the controversy between the particular attempts to define populism rises gradually. This, however, exacerbates the possibility to formulate a minimal definition by cumulating diverging approaches - a proceeding discussed quite critically, anyway (Weyland, 2001). But, comprehending a theory in very general terms as a "system of self-consistent statements" (Kalina et al., 2006, p. 30), even the latter conception requires a common core that

1. For helpful comments on this article, I would like to thank Birgit Altmann, Sophie Haring and Dr. Ondřej Kalina.

2. For a classic description of populist movements in the Latin American context cf. Hennessy (1969) and Dubiel (1986) for different notions of different academic disciplines (Dubiel, 1986, p. 36f).

3. Kazin's contribution is admittedly very descriptive, wherefore Westlind (1996) and Laclau (2005a and 2005b) should be considered as they present theoretically more substantiated approaches. 
can serve as the centre of the associated statements. Hence, attempts to build a theory encounter severe problems when they are discordant with the question which "detail of the political reality" (von Beyme, 1986, p. 15) they shall deal with. Or, referring Popper's bon mot ${ }^{4}$ and adopting it to our case: Populism research is still not sure about what "world" it wants to catch with its "net". Therefore, populism, being a "particularly confusing concept" (Weyland, 2001, p. 1), sticks to a pre-theoretical level that is, even after more than 50 years of research activity, ${ }^{5}$ far away from fulfilling the requirements of theoretical consistency that adherents of a positivist epistemology would exact (Van Evera, 1997, p. 17-21).

Parting from the presupposition that populism is a not a coherent theory, the crucial question is how to find a passable modus operandi to deal with a concept that is exceedingly blurred because of the variety of phenomena that have been assigned to it. This article will show that the conceptual impasse populism research is confronted with arises from diverging paradigms that derive from differing analytical strategies and, hence, ontological and epistemological premises. Thus, the subsequent argumentation will be pursued: To begin with, I will show that three paradigms structure the research field - precisely empirical-inductive, phenomenological-descriptive and discursive approaches - focusing on distinctive aspects as well as similarities. As a next step, I will demonstrate that the utility of an approach depends on the object of study it addresses. Comparable to Singers level-of-analysis-problem in IR Theory (Singer, 1961), I will argue that debates on populist phenomena should consider the fact that the level of analysis limits the variety of applicable approaches as well as their possible outcomes.

Therefore, the main desiderata of this paper are, first of all, to demonstrate which paradigms structure the opaque field of populism; second, to evaluate the resulting approaches considering their outcomes and impasses; and third, to enunciate suggestions on the question how some additional value can be obtained from this dilemma. As a result, this paper's contribution is an attempt to systematize a highly fragmented debate whereas it does not point at content-related discussions but rather at the pragmatic handling of research paradigms. Or, referring to Meyers: If Popper is right with his metaphor that a "theory is a net thrown to catch the world" (Popper, 1976), than different nets will catch different worlds and explain them in different ways (Meyers, 2006, p. 457).

\section{"Paradigms and Sand-Castles" - Approaches towards a theory of populism}

To each his own definition of populism, according to the academic axe he grinds. (Wiles, 1969, p. 166)

Although the debate on populism appears to be confusing as a result of the multiplicity of disciplines involved in it (Dubiel, 1986, p. 36f) and the plurality of phenomena considered by it, the manifold positions can be regrouped around three analytical notions. ${ }^{6}$

Empirical-inductive strategies ask for the core definition of populist manifestations: "Does it have any underlying unity, or does one name cover a multitude of unconnected tendencies?" (Ionescu et al., 1969, p. 1) Its intrinsic epistemology is palpably idiographic: Starting with historic manifestations of populism, these approaches attempt to induce criteria that could be generalized to sustain a definition of populism at an abstract level. Two "predominant traditions of newer populisms" (Puhle, 1986, p. 15) serve as a historic rootage: ${ }^{7}$ First, grass roots movements that developed in the late $19^{\text {th }}$ century in the US. Second, isochronally prospering Russian Narodnišestvo. The amplitude of case studies that subsequently have been deployed to deduce analytical categories extends over a plurality of cases and countries. ${ }^{8}$ Especially, contributions to

\footnotetext{
4. "A theory is a net thrown to catch the world" (Popper, 1976, p. 31) [Annotation: Translation by the author].

5. If we may consider the conference at London School of Economics in 1967, organized by the journal Government and Opposition, the resulting volume edited by lonescu/Gellner (1969), and the first publications of Torcuato di Tella (1965a and 1965b) and Gino Germani (1968) as the foundational stones for the study of populism.

6. Savarino mentions just two analytical strategies: Generalization, e. g. the building of hypotheses starting from historic manifestations that focus on exogenous determinants of populism, and a reductionist strategy that takes some elements in common as a point of departure to prove the evidence of populism comprehensively and without depending on a particular context (Savarino, 1998, p. 79). However, he disregards important parts of the debate, for example strategies that focus on endogenous determinants of populism or discursive praxis.

7. These two historic cases are those that are consensually acknowledged in the academic debate. Further examples are discussed more controversially. Puhle, for instance, mentions the European socialist left as the third traditional line (Puhle, 1986, p. 15). Worsley, on the contrary adds "contemporary" movements and non-communist regimes in Africa, Asia and Latin America (Worsley, 1969, p. 219). Last but not least, Todorov includes the "völkische" ideology of Germany's $19^{\text {th }}$ century romanticism (Todorov, 2008, p. 1).
}

8. Prototypes of regional studies are the contributions of Hofstadter, Hennessy, Walicki, lonescu and Saul (Ionescu et al., 1969, p. 9-150), 
Latin-American populisms in the first half of the $20^{\text {th }}$ century - in particular with regard to Argentinean peronismo and Brazilian varguismo - accounted for pivotal stimuli and established the "state of the art" for a rather long time. Maybe the most prominent example is the following definition by Di Tella, which has been cited or paraphrased in a considerable number of articles (exemplary: Puhle, 1986, p. 26f; Savarino, 1998, p. 5; Gonzalez, 2007, p. 7f):

El Populismo, por consiguiente, es un movimiento político con fuerte apoyo popular, con la participación de sectores de clases no obreras con importante influencia en el partido y sustentador de una ideología anti-status quo. (Di Tella, 1965b, p. 398)

Following the assumption that the least common denominator of these contributions is that they attempt to condense different empirical cases under one theoretical roof, there are two methodological alternatives at hand that can lead to the development of such a general framework: Either the development of an ideal type, i.e. "a fictional construction that contains the main characteristics of the given phenomenon, while it is not expected to find all these characteristics in any particular case" (Rovira Kaltwasser, 2010, p. 4) or the designation of a minimal definition that determines core attributions of populism. ${ }^{9}$

While the breadth of analyzed phenomena - from the neoliberalization of Latin American populisms (Demmers et al., 2001) to the right-wing populism of the German Schill-party (Hartleb, 2004, p. 173-230) - resulted in a comprehensive supply of case studies, the conclusions drawn from the empirical observations varied heavily (Weyland, 2001, p. 1). Indeed, this causes definitions - both minimal and ideal ones - that rely profoundly on particular contexts or actor constellations and cannot be transferred easily to dissimilar settings. But the question is whether this can be expected at all. At this point, populism research has fallen into an epistemological trap: without a doubt, it would be a benefit for the debate if theories could be built by generalizing observed characteristics. But it is an obvious implication of idiographic research designs that their cognitive interest focuses rather on the interpretation and understanding of societal phenomena than on abstracting them to detect causal explications (Welzel, 2001, p. 404-407) - provided that the theoretical construction upon which the respective definition is based shall not lose its accuracy, ${ }^{10}$ for which Germani regrettably provides evidence:

Populism itself tends to deny any identification with or classification into the Right/Left dichotomy. It is a multiclass movement, although not all multiclass movements may be considered populist. Populism probably defies any comprehensive definition. Leaving aside this problem for the moment, populism usually includes contrasting components [...]. (Germani, 1978, p. 88)

It was foreseeable that critics would centre on this nebulosity. But they advert to a problem that occurs inevitably when attempts at theory building try to integrate strongly diverging phenomena under one theoretic roof: Conclusions drawn from these efforts will necessarily be either contradictory or too general (Canovan, 1981, p. 6f; Canovan, 1982, p. 547). For that reason, Canovan (1981 and 1982) disseminates a phenomenological-descriptive approach to the object of populism that is "concerned with description rather than with explanation, aiming at comprehensiveness in preference to theoretical elegance" (Canovan, 1982, p. 545) and tries to conceive populism taxonomically. ${ }^{11}$ Her main point of reference is the catalogue of criteria developed by Wiles (1969), who regards populism as a real "syndrome" that can be grasped through a combination of varying criteria despite the fact that this implies logical incoherencies and a miscellany of exceptions: "Framed so as to coincide with the natural divisions of the real world, rather than with logical constructs, they will and should fail to cope with existing exceptions" (Wiles, 1969, p. 171). Accordingly, this approach has been criticized first and foremost for the lack of stringency in its premises: First, phenomenological strategies tend to avoid addressing those neuralgic points of the debate that they pretend to solve (Falkenberg, 1997, p. 18 and 26) - namely the problems of conceptual blurring and the inexistence of a core definition. Instead, populism becomes a status that is ascribed a priori to qualify determined characteristics as "populist" - the suspicion that this is a blueprint for

9. An often cited example for the development of an ideal type of populism is Kazin's analysis of populist traditions in the United States (Kazin, 1998). By contrast, for an exemplification of a minimal definition of populism see Muddes' contributions to the study of populist ideologies (Mudde, 2004; Mudde, 2007).

10. Sartori calls this problem "conceptual stretching", circumscribing it as follows: in order to obtain a world-wide applicability the extension of our concepts has been broadened by obfuscating their connotation (Sartori, 1970, 1053).

11. Canovan establishes seven categories of populism: 1) Farmers Radicalism, 2) Revolutionary Intellectual Populism, 3) Peasant Populism, 4) Populist Dictatorship, 5) Populist Democracy, 6) Reactionary Populism and 7) Politicians' Populism (Canovan, 1981; Canovan, 1982, 550f). 
analytical sophism stands to reason. The second critic is a derivate of the latter problem: Congruously, the question emerges upon which criteria a typology is designed if no definition of the object that shall be characterized is carried out. Westlind describes this conceptual dilemma metaphorically when he argues: "For the naturalist to collect beetles, she must first have a notion of what a "beetle" is: otherwise, she could have butterflies, ants, or aardvarks in her beetle collection" (Westlind, 1996, p. 45).

Changing the ontological and epistemological premises that underlie the research strategy could break this analytic deadlock. Discursive approaches deviate from empirical-inductive and phenomenological-descriptive strategies because of two fundamental hypotheses: First, it is argued ${ }^{12}$ that populism is not an ontic but an ontological category "[...] i. e. its meaning is not to be found in any political or ideological content entering into the description of the practices of any particular group, but in a particular mode of articulation of whatever social, political or ideological contents" (Laclau, 2005b, p. 34). In discourse theory, content cannot be presupposed axiomatically because it is constituted in the field of discourse. Accordingly, content centred approaches towards populism are doomed to failure and argumentative inconsistency because the empirical search for a common "ontic" nucleus that could be taken as a basis to define populism leads to a cognitive logjam due to an ontological discrepancy. Discursive practices follow underlying articulatory logics that lead to the production of social realities - e. g. contents. Thence, the focus of populism analysis should move from certain contents to these articulatory practices (Laclau, 2005b, p. 32f). Second, following Laclau, populism has no "referential unity because it is ascribed not to a delimitable phenomenon but to a social logic whose affects cut across many phenomena" (Laclau, 2005a, p. xi). More precisely, as it is a social logic, it is inherent in social practice and politics to a greater or lesser extent. Here, the first problem emerges: If populism is immanent in politics, the question is how to distinguish both practices. Although Laclau underlines the floating continuum in between (Laclau, 2005b, p. 45), the concept of a phenomenon that is not delimitable unavoidably loses its analytical accuracy. In addition to that, the focus on structural causes of populism would degrade the latter to the status of an epiphenomenon (Laclau, 2005a, p. 17): populism would be considered to be the expression of determined structural conditions - and the mode of political articulation that derives from this constellation would not be in need of explanation. Therefore, Laclau emphasizes the performative disposition of populism as a discursive practice - repudiating, at the epistemological level, the idea of causal relations between structural determinants and its populist consequences.

This brief, yet comprehensive tour d'horizon has made clear the evident cleavages concerning modalities and finalities that separate the approaches. But there are also some boundary points within the debate: Even though the epistemological premises of the empirical-inductive and the discursive concepts could not be any more contrary, they have in common the demand to contribute to a contextindependent, generalizable conceptualization of populism. On the other hand, the proximity between the phenomenological and the discursive strategies is caused by the conjoint thesis that, on the basis of empiric observations, no core definition can be condensed which could function as a fundament for a general theory of populism.

\section{Populism and political systems - a level-of-analysis problem?}

Apparently, research paradigms have a strong influence on the descriptive and explanatory potential of their results as they all are subject to restrictions that are inherent to the range of analytical strategies they offer and the types of study objects they can cover. But, contrariwise the issue emerges whether the utility of an approach is dependent on the study object it addresses and whether it can be concluded vice versa that the research object limits the variety of approaches that are applicable to it. In political science - and especially in the study of International Relations (Waltz, 2001; Singer, 1961) ${ }^{13}$ - the latter assumption

12. In the following I will mainly resort to the contributions of Ernesto Laclau, because his work is, among discursive approaches in the study of populism, by far the most widely received one (see exemplary: Falkenberg, 1997, p. 16-28; Aboy Carles, 2001; Retamozo, 2006; Priester, 2007, p. 35-40; Link, 2008).

13. Waltz distinguishes three perspectives in the study of international relations, i.e. three images of international relations: First, approaches focussing on the systemic level; second, those that centre the level of the nation state; third, the level of individual action (Waltz, 2001). However, this multidimensional model does not seem to be adequate to capture populist phenomena because individuals play an inferior role in the study of populism. Due to the fact that populism always refers to a certain notion of "the people", it is intrinsically linked to super-individual actors. Therefore, Singer's distinction between a systemic and an actor-centred perspective appears to be more suitable because here the type and constitution of the actor is irrelevant. 
is a bromide, in particular because of Singer's article regarding the level of analysis problem in international relations. He differentiates between two widely employed levels of analysis - the international system and the national sub-systems. Concerning these levels, an essential decision both physical and social scientists have to take is whether "to focus upon the parts or upon the whole, upon the components or upon the system" (Singer, 1961, p. 77).

By contrast, in the study of populism reflections on this question remain scarce, though the concept of political systems (Easton, 1957; Almond, 1956; Parsons, 1976), being constituted by two basic elements - the system's structure and its actors predominates, which points directly to this problem. Following the established praxis in social sciences to use the researcher's viewpoint - e. g. his position on the micro- or the macro-level - for perspective differentiation (Schülein, 1983, p. 14), the focus on the structure or its elements could be taken as a basis to distinguish between "levels-of-analysis" in the study of populism, as well.

A look at the predominant debates reveals the practicability of this attempt to systematize the existing approaches:

Structuralist contributions share the assumption that populism has to be considered as a derivate of structural conditions and constellations, respectively. For instance, Ionescu and Gellner opted for the subsequent interpretation:

Perhaps, [...] populism was a sort of recurring mentality appearing in different historical and geographic contexts as the result of a special social situation [...]. (Ionescu et al., 1969, p. 3)

Within this perspective, notions differ depending on the independent variable they take account of: ${ }^{14}$ While in some contributions - mainly of Latin American social scientists - socioeconomic aspects prevail, political configurations account for the second part of the bifurcation; the former approaches originate from modernization and dependency theory debates (Shils, 1960; Germani, 1968; Germani et al., 1969; Di Tella, 1965a and 1965b; Stewart, 1969; Ianni, 1975) whereas the latter focus on moments of political crises that led to populist incidence (Puhle, 1986; Dubiel, 1986; Falkenberg, 1997, p. 28; Priester, 2007).

Actor-centred approaches towards populism can be grasped as those perspectives that deal with political actors - movements or parties for example and the consequences of their actions for the political system that surrounds them. These concepts usually concentrate on the type of populist actor or the question whether a particular "populist style" (Knight, 1998) or a "populist strategy" (Weyland, 2001) exists and how it manifests itself.

The essential question is, at this point of the debate, how the adopted level of analysis accounts for diverging analytical capacities. In analogy to Singer's essay on the level-of-analysis problem in International Relations (Singer, 1961) both structuralist and actorcentred perspectives promise different outcomes and problems: while the advantage of systemic perspective is its comprehensiveness of the system, it suffers from a lack of descriptive detail. And it tends to overemphasize systemic determination and to assume certain uniformity between the actors. Interestingly, in particular socioeconomic structuralist approaches suffered badly from the criticism that they would underestimate the autonomy of the political sphere (Krasner, 1984; Evans et al., 1985) and the allegation that its teleological-historicist notion of modernization (Weyland, 2001, p. 6) would cause perspective reductionism because it fixes populism to a determined historic stage of societal development (Laclau, 1981; Westlind, 1996, p. 51). In consequence, these concepts could not explain two important empirical incidences: first, there is no evidence for the compulsive linearity of transition processes they presuppose. Second, they had no explanation for the recurrence of (neo-) populist leaders in the 1980s and the 1990s under completely altered socioeconomic circumstances (Demmers et al., 2001; Weyland, 2003). While subsystem-centred perspectives avoid getting caught in this trap and benefit from the fact that they permit significant differentiation among the actors, they are confronted with a new type of questions: Where do the actors' motivations derive from? Which factors influence the actors' behaviour and how do the actors perceive these factors? And, beyond that: What constitutes the actors that these approaches intend to analyze? Since both strategies are not combinable, scholars will necessarily have to choose - depending on the type and purpose of their research.

\section{Conclusion}

Picking up the initial reference to Meyer and Popper, it became clear that different approaches towards populism catch diverging phenomena as a logical consequence of ontological and epistemological premises. Empiric-inductive approaches focus on theory building through a generalization

14. Viguera (1993), for example, distinguishes in a comparable way between populism as a political-ideological phenomenon and populism as a result of socioeconomic aspects and policies. Later, discussing neopopulism, he opts for a stronger actor-centred perspective. 
of empiric observations, aiming at the condensation of a core definition. By contrast, phenomenologicaldescriptive strategies concentrate rather on the description of populist phenomena and the design of taxonomies. Both of them regard social reality, and consequently populist contents, as given a priori whereas discursive approaches address the problem of how such social realities are constituted. As a result, diverging ontological predispositions and the resulting epistemological inclinations dissociate the existing notions of populism and enforce the formation of paradigms - with oftentimes accentuated incompatibilities and always direct consequences on the selection of the phenomena to be analyzed and the research strategies to be applied. On the other hand, as perspectives on potential study objects vary significantly in the level of analysis adopted, the choice of a micro- or macro-perspective becomes a second determinant that influences the applicability of analytical approaches and their descriptive and explanatory capacities.

What lessons can be drawn from these observations? First of all, scholars need to be aware of this paradigmatic bias and behave pragmatically. If research intends to be problem-centred, then the problem should be the decisive factor in methodological choices and not inversely the paradigm affect the selection of which problems to tackle. Referring back to Singer's model, "[...] the problem is really not one of deciding which level [of analysis] is most valuable to the discipline as a whole and then demanding that it be adhered to from now unto eternity" (Singer, 1961, p. 90). Rather it is one of realizaing that the multitude of diverging aspects subsumed under the label "populism" refers to analytical problems that can be situated on differing levels of analysis and, thence, be explored by various approaches with varying analytical capacities. As a consequence, more awareness concerning the descriptive and explanatory implications of the chosen perspective would be essential. Therefore, researchers on populism should start to reflect constructively their research strategies concerning their cognitive interests and ontological and epistemological premises. Situating contributions to populism research in its meta-theoretical context would be conducive to reveal analytically determined potentials and limits - and to avoid unnecessary inter-paradigm-controversies. If populism is a blurred concept with a particularly varying range of approaches to it, scholars should try to take this multitude as an advantage by augmenting methodological rigorousness and deepening the comprehension of single aspects of populism instead of wasting energy on attempts to cumulate incompatible concepts to general frameworks.

\section{References}

ABOY CARLÉS, Gerardo. Repensando el Populismo. In: INTERNATIONAL CONGRESS, LATIN AMERICAN STUDIES ASSOCIATION, 23, Washington D.C., 2001. ALMOND, Gabriel A. Comparative Political Systems. The Journal of Politics, v. 18, n. 3 Ag. p. 391-409, 1956.

VON BEYME, Klaus. Die politischen Theorien der Gegenwart. München: Piper, 1986.

CANOVAN, Margaret. Populism. New York: Harcourt Brace Jovanovich, 1981.

. Two Strategies for the Study of Populism. Political Studies, v. 30, n. 4, p. 544-552, 1982.

DECKER, Frank. Die populistische Herausforderung. Theoretische und ländervergleichende Perspektiven. In:

(Comp.). Populismus: Gefahr für die Demokratie oder nützliches Korrektiv?. Wiesbaden: VS Verlag für Sozialwissenschaften, p. 9-32, 2006.

DEMMERS, Jolle; JILBERTO, Alex E. Fernandez; HOGENBOOM, Barbara (Eds.). Miraculous Metamorphoses: The Neoliberalization of Latin American Populism. London: Zed Books, 2001.

DI TELLA, Torcuato. Populism and Reform in Latin America. In: VELIZ, Claudia (Comp.). Obstacles to Change in Latin America. London: Oxford University Press, p. 4774, 1965a.

Populismo y Reforma en América Latina. Desarrollo Económico, v. 4, n. 16, Abr./Jun. p. 391-425, 1965 b. Populism into the Twenty-First Century. Government and Opposition, v. 32, n. 4, p. 187-200, 1997.

DUBIEL, Helmut. Das Gespenst des Populismus. In: (Comp.). Populismus und Aufklärung. Frankfurt a. M.: Suhrkamp, p. 33-50, 1986.

EASTON, David. An Approach to the Analysis of Political Systems. World Politics, v. 9, n. 3, Abr. p. 383-400, 1957. EVANS, Peter; RUESCHEMEYER, Dietrich; SKOCPOL, Theda (Eds.). Bringing the State back in. Cambridge: Cambridge University Press, 1985.

FALKENBERG, Susanne. Populismus und Populistischer Moment im Vergleich zwischen Frankreich, Italien und Österreich, Duisburg. 1997. Tese (Doutorado em Ciências Políticas) - Universidade de Duisburg, 1997.

FRÖLICH-STEFFEN, Susanne; RENSMANN, Lars. Populistische Regierungsparteien in Ost- und Westeuropa: Vergleichende Perspektiven der politikwissenschaftlichen Forschung. In: (Comp.). Populisten an der 
Macht: Populistische Regierungsparteien in West- und Osteuropa. Wien: Braumüller, p. 3-34, 2005.

GERMANI, Gino. Política y sociedad en una época de transición: de la sociedad tradicional a una sociedad de masas. Buenos Aires: Paidos, 1968.

. Authoritarianism, Fascism and National Populism. New Brunswick, NJ: Transaction, 1978.

GERMANI, Gino; DOS SANTOS, Mario R. Etapas de la modernización en Latinoamérica. Desarrollo Económico, v. 9, n. 33, Abr./Jun. p. 95-137, 1969.

GONZALEZ, Omar. Los Origenes del Populismo latinoamericano. Una Mirada diferente. Cuadernos del CENDES, v. 24, n. 66 (3), Set./Dez. 2007, p. 75-104, 2007.

HARTLEB, Florian. Rechts- und Linkspopulismus: Eine Fallstudie anhand von Schill-Partei und PDS. Wiesbaden: VS Verlag für Sozialwissenschaften, 2004.

HENNESSY, Alistair. Latin America. In: IONESCU, Ghita; GELLNER, Ernest (Comp.). Populism: Its Meaning and National Characteristics. New York: Macmillan, p. 28-61, 1969.

IANNI, Octavio. La Formación del Estado populista en América Latina. México: Ed. Era, 1975.

IONESCU, Ghita; GELLNER, Ernest (Eds.). Populism: Its Meaning and National Characteristics. New York: Macmillan, 1969.

KALINA, Ondřej; KÖPPL, Stefan; KRANENPOHL, Uwe; LANG, Rüdiger; STERN, Jürgen; STRAßNER, Alexander. Grundkurs Politikwissenschaft: Einführung in das wissenschaftliche Arbeiten. Wiesbaden: VS Verlag für Sozialwissenschaften, 2006.

KAZIN, Michael. The Populist Persuasion: An American History. Ithaca, NY: Cornell University Press, 1998.

KNIGHT, Alan. Populism and Neo-Populism in Latin America, especially Mexico. Journal of Latin American Studies, v. 30, n. 2, Maio, p. 223-248, 1998.

KRASNER, Stephen. Approaches to the State. Comparative Politics, n. 16, Jan. p. 223-244, 1984.

LACLAU, Ernesto. Politik und Ideologie im Marxismus: Kapitalismus, Faschismus, Populismus. Berlin: Argument-Verlag, 1981.

. On Populist Reason. London: Verso, 2005a.

Populism: What's in a Name? In: PANIZZA,

Francisco (Comp.). Populism and the mirror of democracy. London: Verso, 2005b. p. 32-49.

LINK, Jürgen. Diskurstheoretische Überlegungen zur neuesten Konjunktur des "Populismus“-Begriffs (mit Bezug auf Ernesto Laclau). In: FABER, Richard; UNGER, Frank (Comp.). Populismus in Geschichte und Gegenwart. Würzburg: Königshausen und Neumann, 2008. p. 17-28.

MEYERS, Reinhard. Theorien der Internationalen Beziehungen. In: WOYKE, Wichard (Comp.). Handwörterbuch Internationale Politik. Bonn: Bundeszentrale für Politische Bildung. 2006. p. 450-482.

MINOGUE, Kenneth. Populism as a political movement. In: IONESCU, Ghita; GELLNER, Ernest (Comp.). Pop- ulism: Its Meaning and National Characteristics. New York: Macmillan, 1969. p. 197-211.

MUDDE, Cas. The Populist Zeitgeist. Government and Opposition, v. 39, n. 4, p. 541-563, 2004.

Populist radical right parties in Europe. Cambridge: Cambridge University Press. 2007.

PARSONS, Talcott. Zur Theorie sozialer Systeme. (ed. por JENSEN, Stefan). Opladen: Westdeutscher Verlag, 1976. POPPER, Karl Raimund. Die Logik der Forschung. Tübingen: Mohr, 1976.

PRIESTER, Karin. Populismus: Historische und aktuelle Erscheinungsformen. Frankfurt a. M.: Campus-Verlag, 2007.

PUHLE, Hans-Jürgen. Was ist Populismus? In: DUBIEL, Helmut (Comp.). Populismus und Aufklärung. Frankfurt a. M.: Suhrkamp, p. 12-32, 1986.

RETAMOZO, Martín. Populismo y Teoría política: de una Teoría hacia una Epistemología del Populismo para América Latina. Revista Venezolana de Economía y Ciencias Sociales, v. 12, n. 2, p. 95-113, 2006.

ROVIRA KALTWASSER, Crisóbal. The ambivalence of populism: threat and corrective for democracy. In: TRABALHO INÉDITO APRESENTADO EM NUFFIELD COLLEGE, University of Oxford, 2010.

SARTORI, Giovanni. Concept misformation in Comparative Politics. The American Political Science Review. v. 64, n. 4, p. 1033-1053, 1970.

SAVARINO, Franco. Populismo: Perspectivas Europeas y latinoamericanas. Espiral, v. 13, n. 138, p. 77-94, 1998. SCHÜLEIN, Johann August. Mikrosoziologie: Ein interaktionsanalytischer Zugang. Opladen: Westdeutscher Verlag, 1983.

SHILS, Edward. The Intellectuals in the Political Development of the New States. World Politics, v. 12, n. 3, Apr. p. 329-368, 1960.

SINGER, David J. The level-of-Analysis Problem in International Relations. World Politics, v. 14, n. 1, Out. 1961, p. 77-92, 1961.

STEWART, Angus. The social roots. In: IONESCU, Ghita; GELLNER, Ernest (Comp.). Populism: Its Meaning and National Characteristics. New York: Macmillan, p. 180-196, 1969.

TODOROV, Antony. National Populism versus Democracy. Eurozine Article, 19 jun. 2008. Available at: <http:// www.eurozine.com/pdf/2008-06-19-todorovantony-en. pdf $>$. Acessed on: 20 abr. 2009.

TOURAINE, Alain. Linker Populismus in Lateinamerika. Neue Gesellschaft. Frankfurter Hefte, n. 5, p. 37-39, 2007. VAN EVERA, Steven. Guide to methods for Students of Political Sciences. Ithaca: Cornell University Press, 1997.

VIGUERA, Aníbal. "Populismo" y "neopopulismo" en América Latina. Revista Mexicana de Sociología, v. 55, n. 3, Jul./Set. p. 40-66, 1993.

VILAS, Carlos M. El populismo latinamericano: un enfoque estructural. Desarrollo Económico, v. 28, n. 111, Out./ Dec. p. 323-352, 1988. 
WALTZ, Kenneth N. Man, the State and War: A theoretical analysis. New York: Columbia University Press. 2001. WELZEL, Christian. Wissenschaftstheoretische Grundlagen. In: MOLS, Manfred; LAUTH, Benjamin; WAGNER, Christian (Comp.). Politikwissenschaft: Eine Einführung. Paderborn: UTB, 2001. p. 395-430.

WESTLIND, Dennis. The Politics of Popular Identity: Understanding Recent Populist Movements in Sweden and the United States. Lund: Lund University Press, 1996.

WEYLAND, Kurt. Clarifying a Contested Concept: Populism in the Study of Latin American Politics. Comparative Politics, v. 34, n. 1, Out. p. 1-22, 2001.
Neopopulism and Neoliberalism in Latin America: How much Affinity? In: INTERNATIONAL CONGRESS, LATIN AMERICAN STUDIES ASSOCIATION, 24, Dallas, 2003.

WILES, Peter. A Syndrome, not a Doctrine: Some elementary theses on Populism. In: IONESCU, Ghita; GELLNER, Ernest (Comp.)... Populism: Its Meaning and National Characteristics. New York: Macmillan, p. 166-179, 1969.

WORSLEY, Peter. The concept of Populism. In: IONESCU, Ghita; GELLNER, Ernest (Comp.). Populism: Its Meaning and National Characteristics. New York: Macmillan, p. 212-250, 1969.

\title{
Um choque de paradigmas: populismo e construção de teoria
}

\section{Resumo}

\begin{abstract}
A pesquisa sobre o populismo muitas vezes parece ser opaca porque o populismo é uma etiqueta atribuída a vários fenômenos. No entanto, os fracassos de construir uma teoria do populismo não são meras consequências de um objeto de estudo nebuloso - eles também resultam de controvérsias ontológicas e epistemológicas entre os paradigmas de pesquisa dominantes precisamente porque os debates não consideram os limites intrínsecos nas estratégias analíticas. Este trabalho demonstra que paradigmas estruturam o campo de investigação do populismo e avalia as aproximações resultantes, considerando os seus resultados e impasses. Além disso, sugere propostas à pergunta como algum valor adicional pode ser obtido disso. Por conseguinte, a contribuição deste papel é uma tentativa de sistematizar um debate altamente fragmentado no sentido que não aponta para discussões relacionadas ao conteúdo, mas para o manejo pragmático de paradigmas de pesquisa.
\end{abstract}

Palavras-chave: populismo, construção de teoria, ontologia, epistemologia, paradigmas de pesquisa.

\section{Un choque de paradigmas: populismo y construcción de teoría}

\section{Resumen}

La pesquisa sobre el populismo muchas veces parece ser opaca porque el populismo es una etiqueta atribuida a varios fenómenos. Sin embargo, los fracasos de construir una teoría del populismo no son meras consecuencias de un objeto de estudio nebuloso -ellos también resultan de controversias ontológicas y epistemológicas entre los paradigmas de pesquisa dominantes, precisamente porque los debates no consideran los límites intrínsecos en las estrategias analíticas. Este trabajo demuestra que paradigmas estructuran el campo de investigación del populismo y evalúa las aproximaciones resultantes considerando sus resultados e impases. Además, sugiere propuestas para la pregunta sobre cómo algún valor adicional puede ser obtenido de eso. Por consiguiente, la contribución de este papel es un intento de sistematizar un debate altamente fragmentado en el sentido de que no apunta para discusiones relativas al contenido, pero si al manejo pragmático de paradigmas de pesquisa.

Palabras clave: populismo, construcción de teoría, ontología, epistemología, paradigmas de pesquisa.

Data de recebimento do artigo: 31/3/2010

Data de aprovação do artigo: 12/7/2010. 